\title{
ПРОБЛЕМА НОМІНАЛЬНОГО ВИКОРИСТАННЯ ПЕДАГОГІЧНИХ ТЕХНОЛОГІЙ У ПРОЦЕСІ \\ ГУМАНІСТИЧНОГО ФОРМУВАННЯ ОСОБИСТОСТІ СТУДЕНТА
}

\footnotetext{
У статті з’ясовано поняття педагогічних технологій, використання яких здійснюється на засадах гуманістичного підходу до формування особистості студентів ВНЗ економічного профілю. Визначено основні проблеми їх номінального використання в навчально-виховному прочесі.

Ключові слова: гуманістичний підхід, особистість, номінальність, педагогічні технології.

В статье рассмотрено понятие педагогических технологий, использование которых осуществляется на основе гуманистического подхода к формированию личности студента вуза экономического профиля. Определень основнье проблемы их номинального использования в учебно-воспитательном процессе.

Ключевые слова: гуманистический подход, личность, номинальность, педагогические технологии.
}

Pedagogical technologies, the use of which is performed on the basis of humanist approach to the university economics students personality formation, are considered in the article. The main problems of their nominal use in educational process are determined.

Key words: humanist approach, personality, nominal approach, pedagogical technologies.

Головна мета будь-якого цивілізованого суспільства, що регламентує свою діяльність як холістичну, інноваційну й толерантну, полягає в адаптації до політичних, економічних, соціальних та їм подібних змін. Цей процес неодмінно спричиняє багатоскладову реакцію 3 не менш суттєвими наслідками, вибуховими викликами, що супроводжують етап трансформації глобального суспільства. Отже, у країні з'явилися нові умови господарювання, які передбачають сучасні комплексні підходи до реалізації економічного добробуту країни та іі громадян, забезпечення технологічної, екологічної й економічної компетенцій фахівців.

Оновлення системи освіти відповідно до вимог XXI століття і вимог української державності містить суперечності і труднощі, але головним при цьому $є$ тенденція розвитку на засадах гуманістичної педагогіки. Гострота, якої набула проблема повернення освітньому процесу гуманістичних ідеалів, перетворення традиційної системи освіти на особистісно зорієнтовану вимагає пошуку нових педагогічних підходів $i$ технологій щодо формування змісту освіти, визначення іiі структури, а загалом - до управління навчально-виховним процесом на нових, гуманістичних теоретико-методологічних засадах.

Аналіз науково-педагогічних праць дає підстави стверджувати, що актуалізація особистості студента часто нівелюється в ВНЗ як фактор ії розвитку. Отже, виникає потреба в переосмисленні застосування новітніх педагогічних технологій. Цей явище набуває виняткової актуальності в процесі формування особистості студента вищого навчального закладу, зокрема, економічного профілю 3 погляду потреб нової педагогічної реальності, запитів суспільства і гуманістичного розвитку самої особистості.

Проблеми шляхів гуманістичного виховання широко досліджувались у педагогічній літературі. Обгрунтування гуманістичного, людиноцентристського підходу до виховання здійснили А. Макаренко, В. Сухомлинський, Ш. Амонашвілі, Ю. Бабанський, І. Бех, О. Вишневський, І. Зязюн, В. Кремень, А. Маслоу та інші; системний підхід у процесі виховання дослідили М. Болдирєв, Т. Ільїна, Л. Новікова; сутність і зміст гуманістичного виховання в позанавчальній діяльності висвітлили В. Білоусова, А. Вірковський, О. Гданська, Г. Жирська, В. Киричок, Ж. Петрочко, О. Столяренко, Г. Троцко та ін. Багато 3 науковців присвятили праці окремим проблемам перспективного розвитку гуманістичного виховання особистості студента.

Гуманістична спрямованість інноваційних процесів у системі освіти зумовлена співіснуванням i складними взаєминами в науковій педагогіці й педагогічній практиці традиційної наукової педагогіки, що орієнтована на об'єктивні закономірності виховання й має своїм головним джерелом наукові дослідження i створюваної педагогами-новаторами педагогіки співробітництва. У новаторській педагогіці багатогранно втілена творча сутність навчально-виховного процесу. Якщо наукова педагогіка розвиває загальні закономірності і теоретичні проблеми виховання, то новаторська творить ефективні педагогічні технології.

Проте представники традиційної педагогіки нині доволі критично сприймають виробничий термін «технологія». Ії розуміють як процес 3 кінцевим результатом, що, на перший погляд, важко перенести у педагогічну площину. Думки про технологізацію освіти висловлював ще Я. Коменський 400 років тому. Елементи технологічного підходу спостерігаємо також у роботах більшості видатних іноземних та вітчизняних педагогів - таких як: А. Дистервег, Й. Песталоцці, Л. Толстой, А. Макаренко, В. Сухомлинський. 
Проблемою ефективного застосування педагогічних технологій на засадах гуманістичного підходу розглядали такі російські психологи й педагоги, як: О. Ананьєв, Ю. Бабанський, Л. Божович, Л. Виготський, М. Данилов, Б. Ссипов, В. Загвязинський, О. Ковальов, І. Лернер, М. Махмутов, Н. Морозова, С. Рубінштейн, М. Скаткін, Г. Щукіна та ін. Упровадження активних нетрадиційних методів у навчальний процес студентів економічного напрямку обгрунтовує багато українських дослідників і вчених. Наприклад, Г. Астапова і Г. Козлова, які досліджують комплексну методику підготовки економістів, С. Шоно, О. Друзюк, висвітлюють проблеми застосування окремих педагогічних технологій в активному навчанні студентів. На додаток, цією тематикою опікувалися І. Бех， В. Буряк， Н. Бібік， В. Вербицький，О. Глузман， С. Гончаренко， Л. Гордон， В. Свдокимов О. Киричук, Б. Кобзар, Л. Кондрашова, Г. Костюк, В. Корнєєв, В. Кремень, В. Лозова, В. Мадзігон, I. Малафіїк, Р. Науменко, В. Онищук, В. Оржеховська, В. Паламарчук, І. Підласий, Р. Пріма, О. Савченко, О. Синиця, А. Сологуб, С. Сонько, В. Сухомлинський, О. Сухомлинська, Т. Сущенко, Г. Штельмах, М. Ярмаченко та ін.

Проблемам розвитку педагогічних технологій присвятили свої дослідження зарубіжні представники: Р. Бенуа, Дж. Д. Брунер, У. Джеймс, М. Дональдсон, К. Ізард, І. Лінгард, А. Маслоу, Ж. Піаже, В. Оконь, Я. Рейковський, М. Сміт, Дж. Д. Філіпс, І. Хофман та ін.

Mета статmi - розкрити сутність педагогічних технологій, проблематики номінальності їх використання в процесі формування особистісних і професійних якостей майбутнього економіста на засадах гуманістичного підходу до виховання й навчання.

Відповідно до мети визначено такі завдання:

проаналізувати стан досліджуваної проблеми в педагогічній теорії й охарактеризувати процес організації гуманістичного виховання студентів вищих навчальних закладів економічного профілю в сучасних умовах;

визначити поняття «педагогічна технологія»;

розкрити номінальність проблеми використання педагогічних технологій у процесі розвитку особистості студента.

В умовах реформування усіх сфер життєдіяльності українського суспільства особливої ваги набуває здатність вітчизняної освіти перейти на інноваційний рівень розвитку. Українські вчені В. Андрущенко, I. Зязюн, М. Згуровський, В. Кремень, М. Михальченко, М. Степко та ін. виокремлюють низку факторів, які підтверджують можливість позитивного розв'язання суспільством нагальних проблем трансформації освіти. Зокрема підкреслюється, що суспільні, економічні, технологічні та інші запити сучасного світу, інформаційна революція та формування суспільства, побудованого на знаннях, висувають нові вимоги до методологічної, світоглядної, системної підготовки сучасних фахівців, особливо фахівців економічної галузі на яких сьогодні покладають великі надії з боку розбудови держави. Сукупності цих вимог відповідає інноваційна спрямованість освіти, яка останнім часом стає важливою основою їі подальшого розвитку.

Як результат значного продукування й розповсюдження нових інноваційних знань у різноманітних сферах людської діяльності зростає необхідність у фахівцях із розвинутими аналітичними здібностями, умінням розв'язувати специфічні міждисциплінарні завдання. Пріоритет у цьому напрямку розвитку має такий складник забезпечення компетентності й кваліфікованості фахівця як освіта. На нашу думку, в Україні, як і в багатьох інших країнах пострадянського простору, сформувалася активна тенденція підготовки фахівців з економічного напрямку. Цей факт має право на існування завдяки глобальним, інноваційним, технократичним процесам сучасності. Зростаюча потреба в спеціалістах економічної сфери підвищує попит на економічну освіту та пропозиції роботодавців. Цей же процес сприяє підвищенню якості економічної освіти.

Відтак перетворення особистості студента-економіста на «ділка» зумовлено швидкими темпами розвитку, що є характерними для науково-технічної революції, складними соціальними діями і цілями, деформацією моральності. За словами М. Бердяєва, стан сучасної ситуації можна охарактеризувати таким чином: «Людська душа не може витримати тієї швидкості, якої від неї вимагає сучасна цивілізація...Технічна цивілізація за суттю своєю імперсоналістична. Вона не хоче знати особистості. Вона вимагає активності людини, але не хоче, щоб вона була особистістю. Діяч і підприємець - продукт ...перетворення «теплих, душевних суспільств» на відкриті - «вільні, холодні цивілізації» [5, с. 16].

Зауважимо, що саме в цей момент необхідно згадати про наявність ефективного підходу розвитку і навчання особистості як гуманістичний підхід. 3 позиції гуманізму, людина - це самовитвір і найвища цінність. Інтереси, права й свободи людини є пріоритетними. Люди всі рівні й різні. Діалектична сутність гуманізму полягає у створенні кращого життя для особистості через іï розвиток і розвиток усього людяного в суспільстві й в світовому товаристві. Не тільки всі люди одного виду homo sapiens, але «лише все людство разом $є$ істиною людиною» (І. Гете), а без особистості людство $\epsilon$ неповним. Не тільки «людина $є$ мірою всіх речей» (Протагор), але і гуманізм є міра людини й суспільства. Не тільки «звання людини є вищим за всі можливі людські звання» (Л. Толстой), але й гуманне суспільство - найвищий ідеал людства. На думку академіка В. Кременя, сьогодні особливої 
уваги набуває «проблема людиноцентризму освіти, незважаючи на напрям підготовки майбутнього фахівця» [5, с. 15].

Отже, зазначені вище факти надають нам змогу підтвердити значення гуманістичного підходу до навчання майбутніх економістів. Цей підхід, на думку Г. Ковальчук, має суттєвий зв'язок із мотиваційним аспектом особистості i формує ставлення до іншої людини як до цінності; спрямованість на відкрите й активне спілкування; прагнення до самовдосконалення; установка на творчість; націленість на гармонійний розвиток тих, хто навчається.

За словником С. Ожегова, технологія - це сукупність процесів у певній галузі виробництва, а також науковий опис способів виробництва [6, с. 363]. Технологія (від грец. Теchne-мистецтво, майстерність, уміння, логія, від грец. Logos - слово, вчення) - сукупність методів, які здійснюються у будь-якому процесі. Звідси, педагогічна технологія - сукупність правил і відповідних їм педагогічних прийомів і способів впливу на розвиток, навчання і виховання студента.

Поняття «педагогічна технологія» останнім часом дедалі більше поширюється в науці й освіті. Його варіанти - «педагогічна технологія», «технологія навчання», «освітні технології», «технології в навчанні», «технології в освіті» широко використовуються в психолого-педагогічній літературі і мають понад 300 формулювань, залежно від того, як автори уявляють структуру і компоненти освітнього процесу. Аналіз еволюції поняття «педагогічна технологія» дає змогу прогнозувати технологічні тенденції в освіті. Трансформація терміна від «технології в навчанні» до «технології освіти», а потім до «педагогічної технології» - детально продуманої моделі сумісної діяльності щодо проектування, організації та проведення навчально-виховного процесу з безумовним забезпеченням максимально комфортних умов як викладачеві, так і студенту.

Поняття «технологія» в педагогіці має декілька аспектів:

- усі засоби педагогічної взаємодії;

- технологія навчання - система методів, прийомів і дій учителів та учнів у процесі навчання;

- технологія виховання - система методів, прийомів і дій вихователя та вихованців у спільній діяльності, зміст якої полягає в засвоєнні норм, цінностей, стосунків;

- інформаційні технології, які можна використовувати для організації процесу навчання.

У педагогіці поняття педагогічних технологій передбачає вживання певного педагогічного інструментарію для досягнення виховних і навчальних цілей. Варіативність педагогічних технологій велика, залежно від поставленої мети, характеру навчання і виховання, особливостей тих, кого навчають, і т. Виходячи 3 цього, важко визначити класифікацію технологій. Держстандартом із професійного педагогічного утворення подано таку класифікацію технологій навчання: репродуктивні, продуктивні, програмовані, алгоритмічні, інформаційні і технології диференціації.

Деякі педагогічні технології по праву можна вважати інтернаціональними. Перодовсім йдеться про модульні технології, які народились у США. Такі технології поділяються на модульнорозвивальні, модульно-кредитні, модульно-рейтингові, модульно-проектні. Починаючи з середини 90-х років XX століття, модульні технології використовуються в українській педагогічній практиці. Першим науковцем, який почав запроваджувати ці технології був О. Алексюк [1, с. 36].

Згідно з О. Гушко, кредитно-модульна система відкриває нові можливості у підготовці фахівців. Ї̈ї впровадженню сприяють такі чинники, як мотивація навчання, потреба в навчанні, застосування знань із практики, періодичність контролю і перевірки знань, обсяг і характер самонавчання [1, с. 37].

Поміж педагогічних технологій широкого розповсюдження набули інформаційні технології, особливо завдяки майже безмежному і безболісному доступу до будь-якої інформації. Під час використання на заняттях інформаційних технологій підвищується мотивація навчання і стимулюється пізнавальний інтерес, зростає ефективність виконання самостійної роботи. Мультимедія та Інтернет стали засобом виховання, спілкування, інтеграції у світове співтовариство. Багато досліджень присвячено комп'ютеризації освітнього процесу у ВНЗ. Зокрема, було створено низку комп'ютерних навчальних програм, серед яких можна виокремити: комп'ютерний підручник, контролюючі та ігрові програми. Комп'ютерні технології сприяли появі ще однієї форми інноваційного навчання, а саме - дистанційного. До найважливіших рис дистанційного навчання науковці відносять гнучкість, модульність, паралельність, повноту інформаційного доступу, економічність, технологічність та гуманність. Найбільш пріоритетними технологіями гуманістичного виховання у позанавчальній діяльності є такі: інтелектуально-ігрові конкурси, розважальні програми, концерти й творчі звіти колективів художньої самодіяльності та ін. (особливо для тих студентів, які безпосередньо беруть участь у їх підготовці та проведенні), відвідування вистав професійних акторів, спортивні змагання між групами, екскурсії та ін. Методами гуманістичного виховання є лекція, бесіда, переконання, диспут, приклад, вправа, доручення, педагогічна вимога, виховуюча ситуація, змагання, заохочення, покарання.

Отже, під педагогічною технологією слід розуміти вивчення, розроблення і системне використання принципів організації навчального процесу на основі новітніх досягнень педагогіки, психології, теорії управління та менеджменту, інформатики, соціології тощо для розроблення таких засобів навчання, що підвищують ефективність навчального процесу. Логічно буде зауважити, що 
довести перевагу або ефективність того чи іншого підходу, стилю, методу не проста є задачею, тому нормальним $є$ наявність альтернатив у підході до нових технологій.

Проте не всі реально можливі форми гуманістичного виховання реалізуються в дійсності, і не лише через некомпетентність суб'єктів виховного процесу, але й подекуди через відсутність достатніх засобів і прагнення до інновацій. Слід зауважити, що у вітчизняних технічних ВНЗ розвиток особистісних i професійних якостей студентів відбувається часто номінально і в односторонньому режимі.

На нашу думку, ефективна реалізація педагогічних технологій - наприклад, педагогіки співробітництва або педагогіки вільного виховання - неможлива без відповідної взаємодії викладача і студента. При цьому викладач повинен стати зразком самореалізації й самовиховання для студентів. Професійна майстерність, креативність, інноваційних, гуманістична спрямованість, висока психолого-педагогічна й комунікаційна компетенція й вмотивованість $€$ базою для результативного процесу саморозвитку особистості студента викладачем вишу.

Спираючись на аналіз науково-методичних джерел, можна зауважити, що гуманістичні засади виховання наявні у всіх навчальних закладах України, зокрема, і в закладах економічного профілю. Проте вибір педагогічної технології для досягнення певної виховної або навчальної мети має бути зумовлений зацікавленістю як педагогічним складом, так і адміністрацією вищого навчального закладу. Номінальність у виховній діяльності - процес формальний, що не виконує свого призначення, фіктивний. Ситуація, коли ставиться лише галочка у звіті або створюється ілюзія інтерактивності, відповідальності, компетентності з боку викладачів, є антипедагогічним виявом поведінки останніх.

Оскільки сфера педагогіки має іманентну тенденцію розвиватися, змінюватися, вдосконалюватися, iii технології можуть бути як корисними й інноваційними (наприклад, дебати, відеоконференції), так застарілими і недоцільними з позиції цілей, змісту освіти, нових стандартів й ідей виховання. На наш погляд, доцільно констатувати факт нехтування викладачами ролі інноваційних педагогічних технологій і дистанціювання від проблем виховання особистісних і професійних якостей студента. Компетентного фахівця може виховати викладач, який своїм прикладом впливає на прагнення студента до саморозвитку і самопізнання. На підставі такого зауваження можна вивести залежність: невмотивований викладач - невмотивований і ентропічний студент.

Продуктивність різноманітних технологій навчання в багатьох випадках залежить від соціокультурного потенціалу закладу. Незважаючи на прагнення працювати в Європейському освітньому просторі, спостерігається небажання моралізувати і вмотивувати, можливо, 3 причин неякісної підготовки викладачів, низької оплати інтелектуальної праці тощо.

Жодну 3 названих педагогічних технологій не можна назвати домінантною: вони можуть бути використаними лише в системі, у їх комплексній взаємодії. Вища школа насамперед повинна йти пліч-о-пліч із часом. Застосування новітніх педагогічних технологій повинне відповідати змісту навчання і його гуманітарному напрямку.

Ми згодні з дослідниками в тому, що формування прагнення студента до саморозвитку вдається не тільки за рахунок наявних педагогічних технологій і інструментів.С багато інших чинників розвитку особистості студента, що потребують системного підходу, актуалізації соціокультурного потенціалу вітчизняних ВНЗ і тощо. Проте новітні педагогічні технології, безсумнівно, слугують одним із головних інструментів формування компетентного і конкурентоспроможного фахівця. Концепт розвитку особистості студента, 3 нашого погляду, доцільно реалізовувати на основі ціннісно-гуманістичної спрямованості. Розширення бачення й розуміння особистості мають стати базою для зміни пріоритетів ВНЗ, що передбачає наявність вільного виявлення й розвитку особистості не лише студента, а й викладача.

Активний адміністративний пресинг, бюрократизм, застарілість і гальмування професійного розвитку викладача, невідповідне соціокультурне середовище - явища, які, на жаль, залишаються характерними для сучасного ВНЗ. Однак, номінальне використання педагогічних технологій у навчанні й вихованні студента не є загальноузвичаєним. Це питання залишається відкритим для дискусії.

\section{Література}

1. Гушко О. Педагогічні технології підготовки студентів вищих навчальних закладів / О. Гушко // Гуманітарний вісник. - №22. - 2010. - С. 34-38. 2. Зязюн І. А. Концептуальні засади теорії освіти в Україні / I. А. Зязюн // Педагогіка і психологія професійної освіти. - 2000. - №1. - С. 12-13. 3. Зерна педагогічної інновації: [хрестоматія] / уклад. : Л. В. Буркова, Н. Ф. Федорова. - К. : Правда, 2001. - 120 с. 4. Ковальчук Г. О. Активізація навчання в економічній освіті: [навч.-метод. посібник] / Г. О. Ковальчук. - К . : КНЕУ, 2003. - 341 с. 5. Кремень В. Г. Трансформації особистості в суперечностях епохи / В. Г. Кремень // Вища освіта України. - 2010. - №3. - С. 15-17. 6. Ожегов С. И. Словарь русского языка / Сергей Иванович Ожегов. - М., 1988. - 816 с. 7. Педагогічний словник / [за ред. Ярмаченка М. Д.]. - К. : Педагогічна думка, 2001. - 516 c. 8. Реан А. А. Психология и педагогика / А. А. Реан, Н. В. Бордовская, С. И. Розум. - СПб. : Питер, 2002. - 432 с. 9. Рябчиков В. Традиційна педагогічна парадигма як «прокрустове ложе» вітчизняної вищої школи в розвитку особистості студента / В. Рябчиков // Вища освіта України. - 2011. - №3. - С. 32-38. 